\title{
Ecological Consequences of the Digitization of Agriculture
}

\author{
Burliai Alina, Nesterchuk Yuliia, Nepochatenko Olena, Naherniuk Diana
}

\begin{abstract}
The article deals with theoretical and practical aspects of agricultural digitization in the context of sustainable development of society. The levels of digitization of agricultural production have been determined. The basic digital technologies used in agriculture in the context of separate production processes are considered. It is established that the digitization of the agricultural sector of the economy contributes not only to improving the economic efficiency of functioning and competitiveness of the industry, but also allows reducing the burden on natural resources and the environment as a whole.
\end{abstract}

Keywords: Sustainable Development, Agriculture, Digitization, Economic effect, Ecological effect

\section{FORMULATION OF THE PROBLEM}

Agriculture is constantly confronted with the opportunities and risks of technological advancement, which requires a study of their environmental impact. An important element of the greening of agricultural production is the introduction of digitization. In theory and economic policy, it is regarded as an integral part of the fourth industrial revolution and is closely intertwined with material and biological technologies. Businesses are much more likely to use innovative IT solutions that have a positive impact on productivity and streamline production than ever before. Therefore, an important task of modern economic science is to study the risks of digitization in the field of environmental protection.

\section{ANALYSIS OF THE LATEST RESEARCHES AND PUBLICATIONS}

Various aspects of economic digitization have been the subject of research by many scholars. Among them, there are some important researches made by Negroponte N. (1995), Brennen S. (2014), Cieniawska M., Jőrg Rühle (2018), Herlitzius T., Krzywinski J., Rückelshausen A., Weidig K. (2017), Petrenko I. (2018), Klischuk L (2018), Yudina T. (2016).

\section{IDENTIFICATION OF PREVIOUSLY UNSETTLED ISSUES OF THE GENERAL PROBLEM}

Digitalization of agriculture can change the ways and methods of its management and serve as an instrument of

Revised Version Manuscript Received on October 15, 2019.

Burliai A., Asosiated Professor; Uman National University of Horticulture, Ukraine, Europe. (Email: aburlyay@ gmail.com)

Nesterchuk Yu., Professor, Uman National University of Horticulture, Ukraine, Europe. (Email: Nesterchuk1@i.ua)

Nepochatenko O., Professor, Uman National University of Horticulture, Ukraine, Europe. (Email: nepochatenko1@gmail.com)

Naherniuk D., Asosiated Professor; Uman National University of Horticulture, Ukraine, Europe. (Email: diana_nagernyuk@i.ua) change in this sector of the economy. At the same time, there is a need to study the environmental implications of the digitization of the industry. This will contribute to the achievement of the Sustainable Development Goals of the society.

\section{FORMULATION THE GOALS OF THE RESEARCH}

The purpose of the article is to study the theoretical aspects of digitization, practical experience and prospects for its implementation in the agricultural sphere of economy, to evaluate the economic and environmental effects of the introduction of digital technologies in agriculture.

\section{RESEARCH METHODS AND MATERIAL \& RESULTS}

Digitization is an inevitable trend of modern society, which contributes not only to improving the economic efficiency of functioning and competitiveness of the agricultural sector, but also allows reducing the burden on natural resources and the environment as a whole.

Thus, digital transformation in the field of crop production (seeding and fertilizer control systems, software, various sensors, GPS equipment, autopilots and parallel driving systems, flying drones, etc.) leads to the widespread introduction of precise agriculture, resource-saving technologies that will enable to increase production volumes while using less resources and space, ie to become more accurate, stable and environmentally friendly. In addition, it is advisable to introduce digital technologies in crop production with organic production technology at the stage of land analysis and certification, production biologization. For example, almost $60 \%$ of German farmers use digital technologies related to crop risk assessment and weather forecasting [1].

The livelihoods of the livestock sector are also directly linked to the solution of environmental problems, because it creates an opportunity to control the state of feed production, placement and processing of waste, feeding and animal health, which directly correlates with human health and the state of the environment. Thus, in Germany and France, up to $35 \%$ of milking equipment are robots, in Denmark - more than $50 \%$, in the Netherlands - $60 \%$ [2].

However, in terms of use of information technologies, in 2017-2018, Ukraine was only on 74th place in the world (from 137 countries), talking about the availability of the

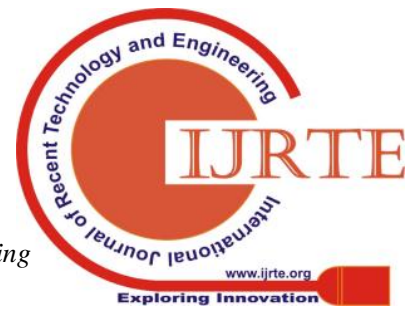


latest technologies - on 107 place [3]. That is, in Ukraine the processes of creation of the digital economy are at the stage of formation and have not yet reached the full level. The domestic economy in the global context remains a soft innovator with a relatively large gap in many factors of innovative development.

Digitization is a term that appeared in the Oxford English Dictionary back in the 1950s. together with the development of computerization. It has two meanings: 1) action, process of digitization, conversion of analog data (text, sound, image, object) into digital form; 2) the deployment or expansion of the use of digital or computer technology in an enterprise, industry, country, etc. [4].

However, by now, the meaning of this term has expanded somewhat and has begun to include not only the technological component, but also the social, cultural and anthropological [5]. This thesis is confirmed by the Ukrainian Institute of the Future, which proves that "digitalization is the introduction of digital technologies in all spheres of life: from interaction between people to industrial production, from household items to toys, clothing and more. It is the transition of biological and physical systems into cyberbiological and cyber physical (combining physical and computational components). Transition of activity from the real world to the virtual world (online)»[6]. Accordingly, digitization products carry the term "digital technologies", and the type of economy where the key factors (means) of production are digital data: numerical, textual, etc., called the digital economy. Digitalization can significantly improve the efficiency, productivity, value of services and goods, and build a digital society [6].

The term "digital economy" was first used by an American intensive development of information and communication technologies, which actually covered all spheres of human life - economic, social, political, cultural, social, etc. [8].

To date, the share of the global digital economy has a rapid upward trend, it is a priority for many economically developed countries and accounts for more than $20 \%$ of the total economy [9]. With the help of digital technologies, countries around the world are accelerating socio-economic development. Almost every sector of the economy is undergoing a transformation by introducing new business models, products, services and, finally, new ways of creating value and jobs. Digital development components are increasingly being integrated into projects in various sectors such as transport, education, health, agriculture and public sector management. The results of this transition are already noticeable: the global digital economy in 2016 was \$ 11.5 trillion. This figure is expected to increase by $10 \%$ in less than ten years [10].

The annual potential for the digitization of industry in European countries is estimated to be at a level of $€ 250$ billion in 2025, which equals the combined value-added potential of $€ 1.25$ trillion. over the next ten years. That is, the expected increase in gross value added from digital transformation is 20 to 30 percent [11]. Successful digitization is exemplified by Estonia, Ireland, Sweden and Israel, which have benefited directly from the integrated development of the digital economy at $20 \%$ of GDP over five years, and the return on investment in digital transformation scientist N. Negroponte [7] in 1995 in connection with the

in these countries reaches $500 \%$.

In general, in terms of digitization, all countries in the world are divided into four groups, characterized by different stages of development.

The group of countries with the highest level of digitization includes naturally developed countries of the world with a high level of GDP per capita and human development index, which is the result of science-intensive and innovative economy. According to the World Bank, in 2018 , Norway ranked third in the country's GDP per capita ( $\$$ 81.8), the US seventh (\$62.6), Australia eighth (\$57.3) [12]. This group includes almost all European Union countries, Japan, Hong Kong and others.

The countries with the lowest level of digitization (0-30\%) include the vast majority of countries in Africa, India, Afghanistan, Uzbekistan, Vietnam and others. These countries are ranked last in the country's GDP per capita and human development index.

Despite the set of negative factors of endogenous and exogenous development, Ukraine has considerable potential for introducing a digital economy and digital transformation of the national economy sectors. It belongs to a group of 28 countries in which the level of digitization is in the range of $40-50 \%$. That is, in the country the vector for economic digitization was selected, which was confirmed by the Concept of Development of the Digital Economy and Society of Ukraine for 2018-2020 adopted in 2018 [13]. It states that the main goal of digitalisation is to achieve the digital transformation of existing and the creation of new industries, as well as the transformation of life spheres into new more efficient and modern ones. Digitalization is a recognized mechanism of economic growth due to the ability of technologies to positively influence the efficiency, effectiveness, value and quality of economic, social and personal activities.

Ukraine has seen an increase in the level of digitization in agriculture, which is a significant part of the country's economy. The industry accounts for about $12 \%$ of GDP and accounts for nearly a fifth of the country's workforce. With the introduction of digital technologies, the agricultural sector can become more refined, environmentally friendly and responsive. This means lowering information and operating costs, providing better services, creating new jobs and simplifying the process of establishing links between farmers, processors, intermediary structures and consumers.

The same opinion is expressed by German scientist Griepentrog Hans W. (2017), who emphasizes that digital agriculture is already an inevitable reality today [14]. At the same time, he emphasizes that there are significant differences in the digitization of agriculture compared to industries. This is due to the peculiarities of agricultural production and its dependence on natural and climatic factors. That is, in the process of digitization of agriculture, a deep understanding of the biological, physical, chemical and socio-economic processes relevant to the industry is required. For example, when optimizing nitrogen dynamics, it is necessary to take into account soil quality, weather, and

Published By: 
crop-related processes, the interaction of all physical, biological, and chemical components. Consideration should also be given to the wide variety of practices, production environments and socio-economic conditions on farms. Such solutions are often more complex and no less scalable than process optimization in manufacturing or communications [15]. Herlitzius (2017) [16] and other researchers point out the lag in the introduction of digital technologies in the agrarian sphere of the economy in comparison with the automation of the industry (automotive). At the same time, they emphasize the huge potential and predict the rapid development of the industry. The main prerequisites for the digitization of the agricultural sector are the optimization of the costs of finance, time and resources (fuel, fertilizers, plant protection products); improving the accuracy of calculations and planning; increase in production productivity; rational use of nature; improving animal welfare; greening of production, etc.

Digital agriculture means the creation, development and application of innovative methods for the use of information and communication technologies in the agricultural sector of the economy. It is defined by the terms "precision farming", "smart farming" and "agriculture 4.0", which mean the development of sustainable agriculture based on digitized production processes.

Different levels of digitization can be identified in agriculture (Fig. 2):

\section{Increasing economic and environmental performance}

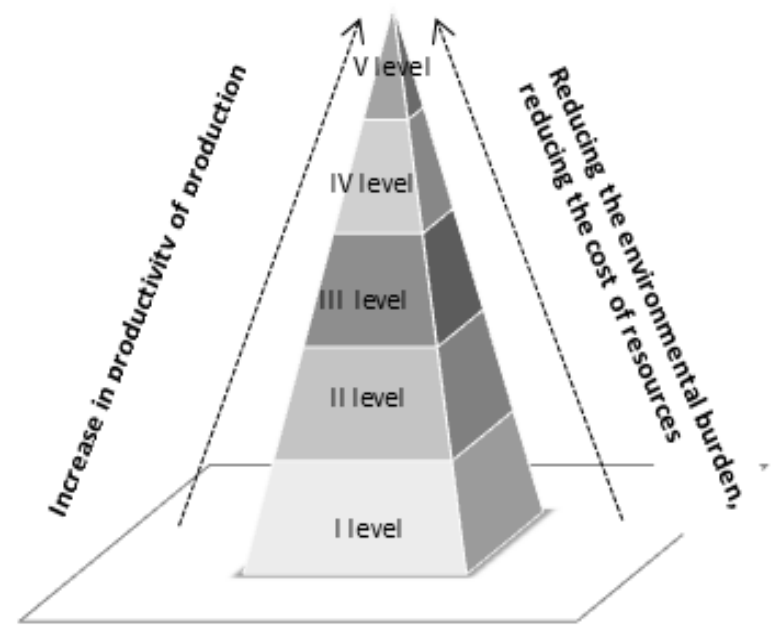

Figure 2 - Levels of agricultural digitization

(generated by authors using source [17] and own research)

Level $I$ is the use in the production process of only one computerized object, such as a machine equipped with sensors, which after processing transmits information directly to the operator;

Level II is the formation of complex objects, for example, tractor units, which are interconnected by an information system with the ability to exchange data to optimize the operating parameters of both tractor and machine;

Level III is an object connected to a network; an example would be a system consisting of several agricultural machines that are interconnected and operated automatically (self-propelled combine, trailers, transport kit, tractor);
Level $I V$ is a digital production system that includes not only individual machines and machine units, but also individual links in the technological chain;

Level $V$ - the highest level of digitization - is a comprehensive mix of systems that are interconnected [17].

We believe that it is advisable to depict graphically the levels of agricultural digitization in the form of a pyramid, which will show a reduction in the number of individual operations with increasing levels. The above also leads to the conclusion that the increase in the level of digitization of production processes in agriculture directly correlates with the efficiency of production, and inversely proportional to the cost of resources and the load on the environment.

Despite the obvious benefits of digitizing the industry, such technologies are nowadays high-value and affordable only for large agro-enterprises. That is why, in Ukraine, some elements of precise farming technology cover only 20-30\% of land and, according to InVenture, only $10 \%$ of Ukrainian agro-companies implement digital technologies [18].

Consider the basic digital technologies used in agriculture by individual production processes.

Driving in parallel. These are high-tech systems that allow high-quality parallel driving of the tractor with maximum accuracy throughout the length of the rows of fields. The system works regardless of time of day and weather conditions. A GPS device is installed to perform various technological operations.

The main advantages of the application of this technology are the increase of labor productivity and intensity of use of agricultural machinery, increase of quality and speed of performance of various technological operations, reduction of gaps and overlaps (by 5-10\%), less wear of equipment, increase of accuracy of field work (up to $4 \mathrm{~cm}$ on sowing) .

The economic effect is to save fuel, seeds, fertilizers and plant protection costs by $15 \%$ [19].

Standards management. Focuses on the automatic application of seeds, fertilizers, herbicides, chemicals, feed and more. It is used in the process of crops, fertilizers and plant protection products, irrigation, fertilization, spraying, feeding animals. It uses different technologies: multispectral and hyperspectral cameras, satellite images, application equipment. In Ukraine, it is used on an area of 800 thousand hectares.

The advantages of this technology are the savings of fertilizers, plant protection products and other resources by introducing the necessary norms to meet the needs of a particular area of the field, introducing optimal standards for achieving the planned yield, the ability to make decisions for each specific area, optimizing the processes of balanced feeding of animals.

The economic effect is to save resources by $10 \%$, increase profits by increasing crop yields and animal productivity.

Soil analysis. Soil analysis includes: scans to determine structure and conductivity; Penetrometer measurements - for a map of sealing and analysis of the destruction of the underwater sole; agrochemical analysis - determining the content of the batteries. 
The relative ability of the soil to provide nutrients for crop production over a given growing period is assessed and the need for lime and diagnosis of excessive salinity or alkalinity is determined. This technology allows you to determine the required amount of fertilizers for a particular field, to select a specific type of culture or technology as a whole, to determine the potential of the field and to predict yields.

The economic effect is to reduce production costs, optimize fertilizer application, increase yields and increase efficiency by $10-30 \%$ [19].

Drones are a tool for remote monitoring and control as well as spectral diagnostics. This is the main way to get accurate data. Drones also perform a transport function when spraying certain areas, delivering parts, etc. The drone market in Ukraine is \$ 12 million. US, $40 \%$ of drones are used in agriculture. Profits from the use of drones in the agricultural sector by specialists are estimated at $\$ 75$ billion by 2025 by creating new jobs and streamlining existing processes.

The advantages of this technology are operational field monitoring; high accuracy of identification of problem areas with GPS strapping; quality control of sowing, tillage; quality control of agricultural machinery; differentiated fertilizer application; high-precision field measurement based on terrain; seedlings and biological yield calculation, potential fertility assessment, irrigation systems monitoring and optimization of irrigation and water consumption, grazing of livestock.

The economic effect is to save fuel by optimizing the number of cultivation and pathways of technology, minimizing the use of seed, fertilizers and irrigation water by preventing their unproductive costs, preserving and increasing the yields through timely sowing and harvesting, differentiated dependency, differentiated in the conditions of a specific field, fertilizing, irrigation, carrying out the processing of poison chemicals; prevention of crop losses due to poor technological operations, damage to diseases and pests, thefts, etc .; optimizing production costs and improving the quality of production planning for agribusinesses; clarification of forecasts of yields and profits from sales of products [20].

Satellite monitoring. It is widely used in agribusiness for determination of unfavorable conditions for plant growth, disturbances of their normal development, operative control of normal vegetative development of crops in large areas with the help of spectral indices, which are used for the assessment of vegetation status, content of pigments, nitrogen, carbon, water. Satellite monitoring can inform the farmer in a timely manner about the condition of the soil, the uniformity of crops, the stressful condition of the plants. The information obtained can be used to assess the suitability of land, develop a plan for ameliorative measures, and assess potential yields. With this technology, the number of direct field trips is reduced by $90 \%$.

With regard to the economic effect of satellite monitoring, it is also reflected in the reduction of fuel, fertilizer, plant ultimately leads to increased production profitability.

Weather monitoring. Modern weather station software enables forecasting of weather conditions for a particular field based on current data on air temperature, humidity, wind speed, and more. In some cases, weather monitoring systems protection products, increased production efficiency, which

can increase agricultural efficiency by $10-20 \%$.

Advantages of using this technology are the ability to analyze archival data and predict the outbreak of diseases and their early prevention; accurate determination of the beginning of field work due to the data of measured precipitation and temperatures; connection of weather stations to irrigation equipment and automation of irrigation; analysis of sensors deficiency or oversaturation of moisture and control of irrigation process, etc. [19].

The economic effect is to increase the efficiency of production operations, to increase the yield and its less dependence on climatic conditions, to save the cost of resources, and to improve the financial results.

The examples of the use of digital technologies in the country's agriculture show considerable economic impact from their implementation. At the same time, the agricultural sector faces many challenges posed by climate change, loss of biodiversity, droughts, desertification, unsustainable environmental management, environmental pollution and more. It is becoming more knowledge-intensive, and the availability of the right information at the right time, in the right format, and through the right environment is affecting the livelihoods of many stakeholders in agriculture and related industries. This is why agricultural digitization can be key to addressing a number of environmental issues.

In general, as outlined in the Digital Economy and Society Development Concept for 2018-2020, digital technologies have significant potential for improving the environmental situation in Ukraine, reducing atmospheric emissions and reducing the effects of global warming.

For the purpose of greening agriculture, it is advisable to determine the environmental effect of the introduction of digitization of its production processes (Table 1).

These tables allow to conclude about the positive impact of the digitization of production processes in agriculture on the greening of the industry.

Digital agriculture in Ukraine is developing in a limited way because of the structural, institutional and economic barriers in the country. At the same time, one should not ignore the dangers that the digitization of the agricultural sector of the economy entails. Among these, it is important to highlight the following risks:

- Technology reliability and data sovereignty. One of the features of agriculture is the close interplay of biological and technological factors of production, and any technical malfunctions (such as a hacker attack) can cause major problems in the short term. This is especially true for the livestock sector and the feeding, milking and other processes. In the field of crop production, similar risks may arise when fertilizing or fertilizing plants. In addition to economic losses, this can be dangerous to animal health and the environment in general.

As for data retention, there are also risks of information leakage, which will reduce the competitiveness of enterprises.

- The introduction of digitization requires a continuous increase in the level of education of agricultural producers. 
At the same time, traditional knowledge and approaches to agribusiness are losing importance. This can cause social conflict between the younger and older generations.

- Innovation and high technology of digitization require highly skilled workers, and some of the low-skilled work will be done automatically. This can lead to an increase in the unemployment rate in the labor market and, as a consequence, an increase in negative social phenomena.

Table 1 - Comparison of economic and environmental effects from the introduction of digital technologies in the agricultural sector *

\begin{tabular}{|c|c|c|}
\hline Tech-nology & Economic Effect & Ecological Effect \\
\hline 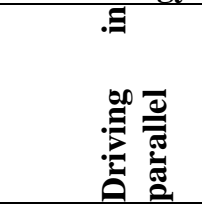 & $\begin{array}{l}15 \% \text { fuel, seed, fertilizer and plant protection cost } \\
\text { savings }\end{array}$ & $\begin{array}{l}\text { reducing the load on land resources, improving soil } \\
\text { structure and reducing its compaction, reducing the } \\
\text { amount of fertilizers and plant protection products }\end{array}$ \\
\hline 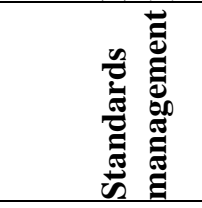 & $\begin{array}{l}\text { resource savings of } 10 \% \text {, increased profits through } \\
\text { increased crop yields and animal productivity }\end{array}$ & $\begin{array}{l}\text { automatic application of fertilizers, herbicides, } \\
\text { chemicals reduces the negative impact on land and } \\
\text { water resources, reduces the level of emissions into } \\
\text { the atmosphere }\end{array}$ \\
\hline 参 & $\begin{array}{l}\text { reducing production costs, optimizing fertilizer } \\
\text { application, increasing yields and increasing } \\
\text { efficiency by } 10-30 \%\end{array}$ & $\begin{array}{l}\text { optimizing fertilizer application, improving soil } \\
\text { structure by identifying the need for lime and } \\
\text { diagnosing excessive salinity or alkalinity }\end{array}$ \\
\hline$\stackrel{\mathscr{E}}{\stackrel{\mathscr{E}}{0}}$ & $\begin{array}{l}\text { fuel saving, minimizing the use of seed, fertilizers } \\
\text { and irrigation water, preserving and increasing } \\
\text { crops through timely sowing and harvesting, } \\
\text { optimizing production costs and improving the } \\
\text { quality of production planning for agribusinesses }\end{array}$ & $\begin{array}{l}\text { rational use of land and water resources, optimal } \\
\text { application of plant protection products through the } \\
\text { use of spot spraying technology in specific areas of } \\
\text { the field. Possibility of using bio-organisms }\end{array}$ \\
\hline 象 & $\begin{array}{l}\text { cost savings of fuel, seeds, fertilizers and plant } \\
\text { protection products, increase of production } \\
\text { efficiency, possibility of land suitability } \\
\text { assessment, development of reclamation plan, } \\
\text { estimation of potential yield }\end{array}$ & $\begin{array}{l}\text { economical impact on the environment of } \\
\text { chemicals through their optimum application } \\
\text { according to the mapping of fields and crops }\end{array}$ \\
\hline 車 & $\begin{array}{l}\text { increase of efficiency of production operations, } \\
\text { increase of yield and its less dependence on } \\
\text { climatic conditions, economy of expenses on } \\
\text { resources, in improvement of financial results }\end{array}$ & $\begin{array}{l}\text { creation of an archive of data of natural and } \\
\text { climatic conditions of the territory }\end{array}$ \\
\hline
\end{tabular}

* formed by the authors based on their own research

- Digitization trends in agriculture show high efficiency from its implementation in large companies with large scale production. This can accelerate structural change in the industry and also have negative social and environmental impacts.

However, in our opinion, the possible risks of the introduction of digitization in the agricultural sector will not stop its rapid progress, since the most important result for businesses is the growth of profits. That is why it is important at the present stage to develop various programs at different levels to minimize the negative effects of agricultural digitization and sustainable agricultural development in general.

\section{CONCLUSIONS}

Digitization is a trend of modern agriculture, the essence of which is to create, develop and apply innovative methods of using information and communication technologies in the agricultural sector of the economy. Ukraine has significant digital implementation potential. This is especially true in the agricultural sector, which is responsible for the food security of the population and plays a significant role in the country's economy.
The development of digitization in agriculture has a significant economic effect, which is manifested in increasing the efficiency of agricultural production and increasing the competitiveness of the industry. At the same time, it is important to note the positive environmental impact of agricultural de-industrialization, which contributes to the sustainable development of society.

\section{REFERENCES}

1. Cieniawska Monika, Jőrg Rühle. 2018. Analiza potrzeb rolników w zakresie cyfrowej dokumentacji w gospodarstwie rolnym. [W] Konferencja „Rolnictwo precyzyjne w Polsce - dziś i jutro" Analysis of farmers' needs in the field of digital documentation on a farm. [In] Conference "Precise agriculture in Poland - today and tomorrow”). Kamień Śląski, 5-7 lutego 2018.

2. Petrenko, I. (2018): Why are we digitizing? Agribusiness today. URL: http://agro-business.com.ua/agro/podiia /item/10937-navishcho-nam-didzhytalizatsiia.html. (01.10.2019) 
3. The position of Ukraine in the world ranking according to the Global Competitiveness Index 20172018. Ekonomichnyi dyskusiinyi klub.. URL: https://bit.ly/2OnXiSd. (12.11.18)

4. Brennen S. Digitalization and Digitization URL: http://culturedigitally.

org/2014/09/digitalization-and-digitization/ (05.08.2019).

5. Vocabulary: Digitalization URL: http://www.strelka .com/ru/ magazine/2015/02/03/vocabulary-digitalisation (11.09.2019).

6. Fischuk ,V., Matyushko, V., Chernev, E. and others. Ukraine $2030 \mathrm{E}$ is a country with advanced digital economy. Site of Ukrainian Institute of the Future. URL: https://strategy.uifuture.org/kraina-z-rozvinutoyu-cifrovo yu-ekonomikoyu.html\#6-2-1. (09.10.2019).

7. Negroponte, N. (1995). Being Digital. NY: Knopf, 1995. $256 \mathrm{p}$.

8. Yudina, T.N. (2016): Understanding the Digital Economy. Theoretical economics. № 3. P. 12-16.

9. Ryzhenko, O. (2018): Fishchuk V. How the digital economy will change Ukraine. Economic truth, 2018. URL: https://www.epravda.com.ua/columns/2018/01/ 16/633057/ - (02.10.2019).

10. World Bank. Digital Development. URL: https://www. worldbank.org/en/topic/digitaldevelopment/overview (04.10.2019).

11. The digital transformation of industry (A European study commissioned by the Federation of German Industries (BDI) and conducted by Roland Berger Strategy Consultants). URL: http://bdi.eu/media/user_upload/ Digital_Transformation.pdf.

12. World Bank. Data refer mostly to the year 2018. Selecting all countries, GDP per capita (current US\$). URL: https://data.worldbank.org/indicator/ny.gdp.pcap.cd?mos t_recent_value_desc=true $(02.10 .2019)$.

13. On approval of the Concept of development of the digital economy and society of Ukraine for 2018-2020 and approval of the plan of measures for its implementation: the decree of the Cabinet of Ministers of Ukraine from January 17. 2018 No. 67-p. The legislation of Ukraine. Kiev, 2018. URL: https://www.kmu.gov.ua/ua/npas/proshvalennya-koncepciyi-rozvitku-cifrovoyi-ekonomiki-tas uspilstva-ukrayini-na-20182020-roki-ta-zatverdzhennyaplanu-zahodiv-shodo-yiyi-realizaciyi

14. Van Es, H., Woodard, J. (2017). Innovation in agriculture and food systems in the digital age. The global innovation index, 97-104.

15. Griepentrog Hans W. 2017. Green Future - Smart Technology: Chances and challenges of digitalization in agriculture. Dlg Pressemitteilung. DLG Pressenmitteilung, 3 (typescript).

16. Herlitzius Thomas, Jens Krzywinski, Arno Rückelshausen, Klaus Weidig. 2017. Mobile Cyber Physical System concept for controlled agricultural environments. Typescript.

17. BMEL. 2017. Digitalpolitik Landwirtschaft. Berlin: BMEL.

18. Official site of Svarog West Group. URL: http://www.svarog-agro.com/uk/home. (07.10.2019).

19. AGGEEK Handbook "A Guide to Precision Farming. Application of data ». The official site of AGGEEK. URL: AGGEEK.net/ru-blog/didzhitalizatsiya-agrosfery. (11.10.2019).

20. Achasova A. Drones for agrarians. Agrimatics website. URL: https://agrimatika.com.ua/agrokopter-abo-dronpoloviy/. (11.10.2019)

\section{AUTHORS PROFILE}

Burliai Alina. She works at the Department of Economics, Uman National University of Horticulture, Faculty of Economics and Entrepreneurship.

She is the author of more than 70 scientific papers in the field of economics.

Scientific interests are sustainable development, economic mechanism of ecologization of agriculture, green

economy

Nesterchuk Yuliia, Professor, Uman National University of Horticulture, Ukraine.

Dean of the Faculty of Economics and Entrepreneurship of the Uman National University of Horticulture. Author of more than 130 scientific papers in the field of economics. Her fundamental and applied researches are aimed at solving problems of development of integration processes in agrarian and industrial production.

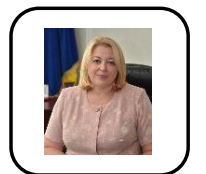

Nepochatenko Olena, Professor, Uman National University of Horticulture, Ukraine.

Rector of Uman National University of Horticulture. Author of more than 150 scientific papers in the field of economics. Her fundamental and applied researches are aimed at solving problems of financial and credit support of business entities

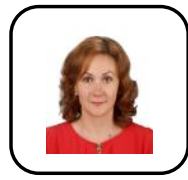

Naherniuk Diana. She works at the Department of the Department of Tourism, Hotel and Restaurant Business, Uman National University of Horticulture, Faculty of Management.

She is the author of more than 30 scientific papers in the field of economics and tourism.

Scientific interests rural development, competitiveness, rural green tourism. 